\title{
Aplikasi Inventaris Aset pada Jurusan Teknik Informatika Universitas Papua Menggunakan Visual Basic dan MySQL
}

\author{
Kristia Yuliawan ${ }^{1}$
}

Jurusan Teknik Informatika, Fakultas Teknik Universitas Papua Jl. Gunung Salju Amban Manokwari

Email: k.yuliawan@unipa.ac.id

\begin{abstract}
Abstrak
Pengelolaan Inventarisasi di Jurusan sangat mempengaruhi kinerja operasi jurusan. Pendataan Inventarisasi di jurusan selama ini masih mengunakan aplikasi Ms. Excel Aplikasi ini membutuhkan waktu yang relatif lama ketika melakukan pendataan asset. Tingkat kesalahan dalam melakukan pendataan juga menjadi tidak terkendali dimana hal tersebut membuat informasi yang di simpan menjadi tidak akurat sehingga proses pencarian data asset membutuhkan waktu yang lama. Adapun jenis penelitian ini mengunakan metode kualitatif dimana metode pengembangan sistem perangkat lunaknya mengunakan metode Extreme Programming. Dengan mengunakan metode ini perangkat lunak yang dikembangkan menjadi lebih cepat, efesien dan fleksibel dimana pendekatanya mengunakan object oriented. Sedangkan untuk pengujian perangkat lunaknya mengunakan metode Black Box. Hasil dari penelitian ini adalah sebuah perangkat lunak Inventaris Aset yang membantu pihak jurusan teknik informatika dalam mempermudah pendataan inventaris barang jurusan.
\end{abstract}

Kata Kunci : Inventaris, Visual Basic, UML, Extreme Programming, Class Diagram

\begin{abstract}
Management of Inventory in the Department greatly affects the performance of the department's operations. Inventory data collection in the department is still using Ms. application Excel This application requires a relatively long time when performing asset data collection. The level of error in data collection also becomes uncontrolled which makes the information stored inaccurate so that the process of searching asset data takes a long time. The type of this research uses qualitative methods where the software system development method uses Extreme Programming method. By using this method the software developed becomes faster, more efficient and flexible where the approach uses object oriented. Whereas for testing the software using the Black Box method. The results of this study are an Asset Inventory application that assists the informatics engineering department in simplifying the inventory inventory of major majors.
\end{abstract}

Kata Kunci : Inventory, Visual Basic, UML, Extreme Programming, Class Diagram

\section{LATAR BELAKANG}

Jurusan Teknik Informatika merupakan salah satu instansi perguruan tinggi yang berada dibawah naungan fakultas teknik universitas papua yang memiliki sumber daya dalam melaksanakan operasionalnya dalam melaksanakan Tridharma Perguruan Tinggi. Jurusan
Teknik Informatika dalam mengelola, mendata inventaris sudah mengunakan komputer yang berkaitan dengan proses administrasi dan manajemennya. Kegiatan administrasi dan manajemen tersebut belum mengunakan program khusus dalam menghasilkan laporan yang berhubungan dengan pengelolaan data dan inventarisasi jurusan hal ini berakibat inventarisasi asset

Program Studi Teknik Informatika

Universitas Prima Indonesia (UNPRI) Medan 
menjadi tidak efektif karena terjadi keterlambatan waktu dalam inventarisasi.

Untuk mengatasi permasalahan diatas, maka perlu dikembangkan perangkat lunak yang khusus dalam menyelasaikan permasalahan pengelolaan asset di jurusan teknikn informatika. Dalam mengembangkan perangkat lunak ini, digunakan metode extreme programming agar pembuatan perangkat lunak ini lebih cepat dalam pembuatanya.

Mamfaat yang diperoleh dari adanya perangkat lunak ini adalah mempermudah dalam mengelola dan menyimpan inventaris asset pada jurusan teknik informatika dengan aman dan akurat sehingga dapat mengefisiensikan waktu dan tenaga dalam mengolah aset.

\section{METODE}

\subsection{Metode Pengumpulan Data}

Dalam melakukan penelitian, teknik pengumpulan data merupakan faktor yang sangat penting demi keberhasilan penelitian, motode yang digunakan penulis sebagai berikut :

a. Studi Pustaka

metode ini dilakukan untuk mendapatkan sumbersumber kajian, landasan teori, pengumpulan data, informasi pengolahan data,penarikan kesimpulan, saran dan impikasinya sebagai penyusunan penulisan

b. Studi Lapangan

Dalam penelitian ini, penulis mengunakan teknik Participant Observation dimana penulis secara langsung terlibat dalam pengumpulan data yang merupakan sumber penelitian. Metode ini sangat menguntungkan penulis dapat mencatat hal-hal yang diperlukan selama penelitian. Dengan metode ini informasi tentang data dapat dicatat dan tidak mengantungkan data dari ingatan seseorang.

\subsection{Metode Pengembangan Sistem}

Metode pengembangan sistem yang digunakan dalam menyelasaikan pembuatan aplikasi ini adalah mengunakan metode Extreme Programming (XP). Adapun tahap-tahap yang ada pada metode ini adalah sebagai berikut :

\section{1) Tahap Eksplorasi}

Tahapan eksplorasi adalah tahapan dimana klien menuliskan kebutuhan-kebutuhan dari sistem yang paling mendasar Setiap kebutuhan yang dituliskan oleh klien akan dibuat dalam bentuk modul yang sederhana atau disebut juga dengan User Stories. hasil dari tahapan eksplorasi adalah mengetahui dokumentasi atas visi dan ruang lingkup pekerjaan.

2) Tahap Perencanaan

Tahapan perencanaan berorientasi kepada tahapan eksplorasi. Tahapan ini akan memperkirakan kebutuhan bisnis, kebutuhan user, dan kebutuhan sistem. Tahapan ini juga akan menghasilkan penjadwalan yang menggambarkan perencanaan waktu pelaksanaan pembangunan sistem.

3) Tahap Iterasi Pengembangan Sistem

Pada tahapan ini, akan terjadi beberapa kali iterasi, setiap iterasi terdiri dari 2 tahapan yaitu analisa sistem, dan pembuatan sistem.

\section{4) Tahap Produksi Akhir}

Tahapan produksi akhir adalah tahapan dimana sistem sudah siap untuk di release. Tahapan ini akan melakukan testing terhadap keseluruhan sistem yang telah dibuat kepada klien.

\section{HASIL}

\subsection{Tahap Eksplorasi}

Pada tahap ini kebutuhan sistem digambarkan dengan user stories dimana hal ini mengambarkan hubungan antara user dengan kebutuhan di dalam sistem.

\section{Tabel 3.1: User Stories}

\begin{tabular}{cl}
\hline User & Kebutuhan Sistem \\
\hline Admin & $\begin{array}{l}\text { Admin sebagai Ketua Jurusan adalah } \\
\text { orang yang melakukan perubahan dan } \\
\text { penambahan asset yang ada. }\end{array}$ \\
\cline { 2 - 3 } Operator & $\begin{array}{l}\text { Operator adalah pegawai administrasi } \\
\text { mempunyai kemampuan untuk dapat } \\
\\
\end{array}$ \\
& $\begin{array}{l}\text { menambah data aset dan dapat } \\
\text { melakukan perubahan data aset yang di } \\
\text { input oleh admin }\end{array}$ \\
\cline { 2 - 3 } Guest & $\begin{array}{l}\text { Guest adalah dosen atau tenaga } \\
\text { kependidikan yang dapat melihat data } \\
\text { keseluruhan asset tetapi tidak dapat } \\
\text { melakukan perubahan apapun. }\end{array}$
\end{tabular}

\subsection{Tahap Perencanaan}

Tahap perencanaan adalah tahap dimana adanya desain awal, sesuai dengan user requirement seperti kebutuhan perangkat keras dan perangkat lunak dan kebutuhan sistem yang dapat diterjamahkan menjadi gambar diagram visual UML sehingga mempermudah dalam pengembangan sistem. Pengembangan sistem yang digunakan adalah use case diagram, class diagram, sequence diagram, collaboration diagram, activity diagram, deployment diagram.

a. Kebutuhan Perangkat Keras 
Perangkat keras yang digunakan dalam penelitian berupa komputer dengan prosesor Intel 2Coree N3350, Memori 2 Gb, Hardisk 500 Gb, dan monitor 14 Inch.

b. Kebutuhan Perangkat Lunak

Perangkat Lunak yang digunakan dalam membangun sistem ini adalah Microsoft Windows 10, Bahasa pemrograman Visual Basic 2010, My Sql, dan Crystal Report.

c. Kebutuhan Sistem

Pada tahap kebutuhan sistem diperlukan analisa terhadap fungsi sistem. Analisa tersebut dapat digambarkan dengan use case diagram seperti pada gambar di bawah ini :

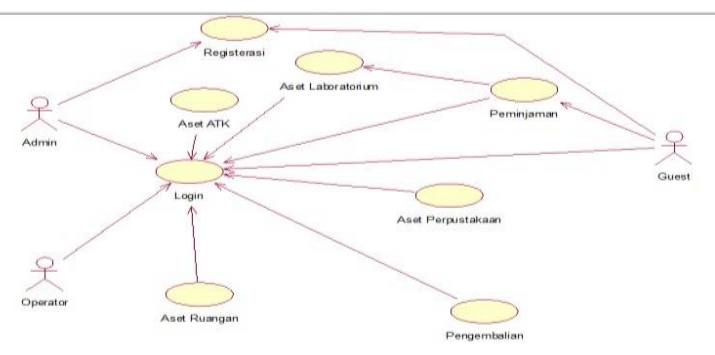

Gambar 3.2 : Class Diagram

\subsection{Tahap Iterasi Pengembangan Sistem}

Pada tahap iterasi pengembangan sistem dilakukan 3 tahap iterasi, tahapan iterasi tersebut sebagai berikut :

1. Iterasi Pertama : Analisa Sistem

Analisa pada iterasi ini difokuskan pada kebutuhan sistem oleh admin, analisa tersebut dapat dilihat pada tabel dibawah ini :

\section{Tabel 3.2 : Analisa Sistem}

\begin{tabular}{ll}
\hline Halaman Admin & \multicolumn{1}{c}{ Fungsi Yang diinginkan } \\
\hline Halaman Depan & $\begin{array}{l}\text { Menu File : Menampilkan menu } \\
\text { login untuk user dan menu keluar } \\
\text { dari sistem. }\end{array}$ \\
$\begin{array}{l}\text { Halaman Menu } \\
\text { Asset } \\
\text { Laboratorium }\end{array}$ & $\begin{array}{l}\text { Menampilkan data asset } \\
\text { laboratorium dan menampilkan } \\
\text { menu peminjaman asset } \\
\text { laboratorium }\end{array}$ \\
$\begin{array}{ll}\text { Halaman Menu } \\
\text { Asset Ruangan }\end{array}$ & Menampilkan data asset ruangan \\
Asset ATK & Menampilkan data asset ATK \\
\cline { 1 - 1 } $\begin{array}{l}\text { Halaman Menu } \\
\text { Asset } \\
\text { Perpustakaan }\end{array}$ & Menampilkan data asset \\
\cline { 1 - 1 } &
\end{tabular}

2. Iterasi Kedua : Pembuatan Sistem
Analisa pada iterasi ini difokuskan pada pembuatan aplikasi sistem inventaris.

a. Tampilan Form Menu Asset Laboratorium Menu daftar asset Laboratorium hak akses admin dapat dilihat pada gambar dibawah ini

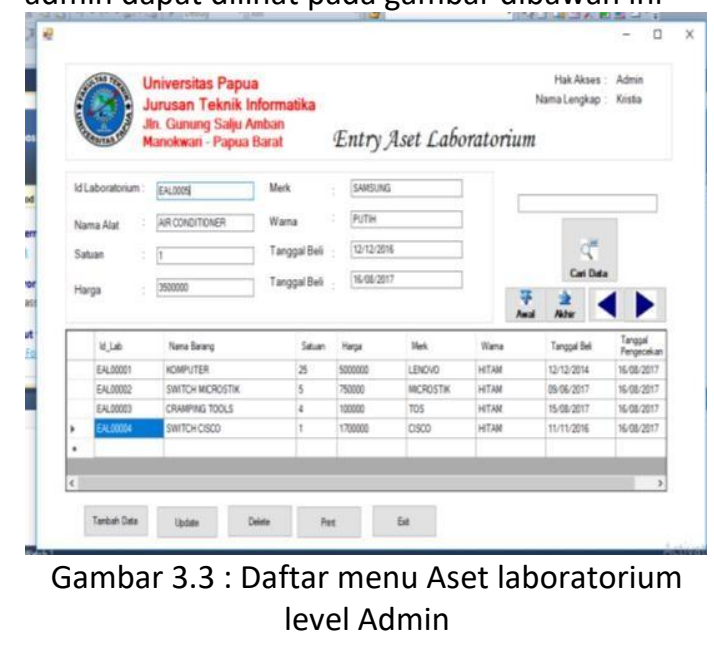

b. Tampilan Form Menu Asset Perpustakaan Menu daftar asset Perpustakaan hak akses admin dapat dilihat pada gambar dibawah ini.

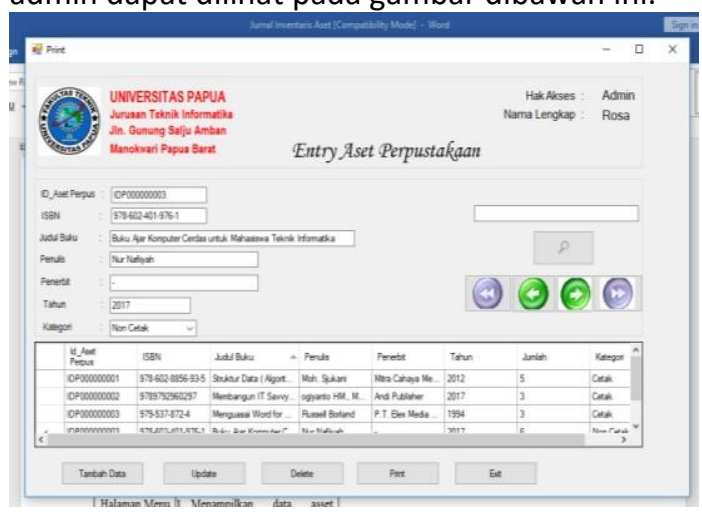

Gambar 3.4 : Daftar menu Aset Perpustakaan level Admin

c. Tampilan Form Menu Asset Ruangan

Menu daftar asset Ruangan hak akses admin dapat dilihat pada gambar dibawah ini.

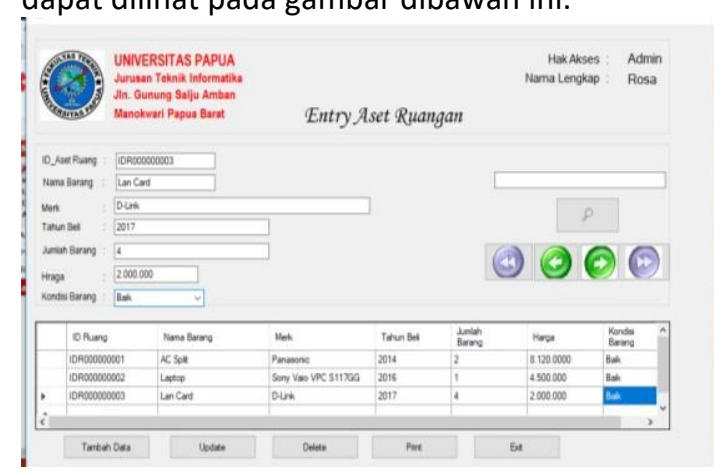

Gambar 3.5 : Daftar menu Aset Ruangan level Admin

Program Studi Teknik Informatika

Universitas Prima Indonesia (UNPRI) Medan 
d. Tampilan Form Menu Asset ATK

Menu daftar asset ATK hak akses admin dapat dilihat pada gambar dibawah ini.

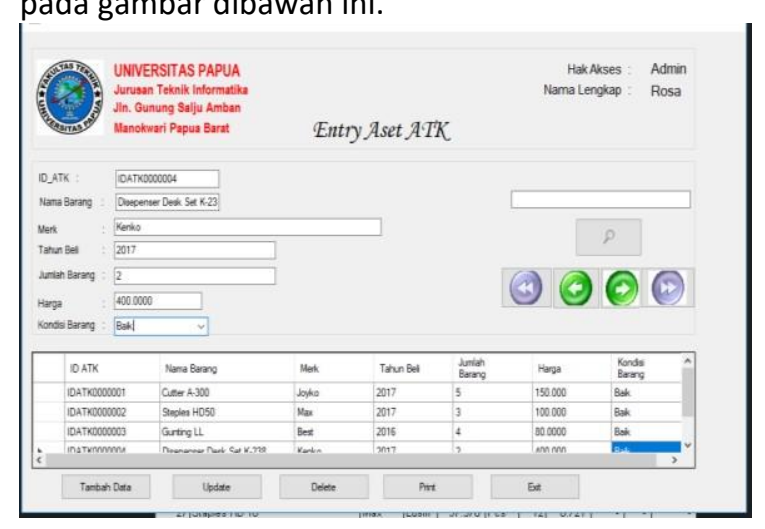

Gambar 3.6 : Daftar menu Aset ATK level Admin

\subsection{Tahap Produksi Akhir}

Pada tabel dibawah ini menjelaskan mengenai fungsifungsi yang yang telah berjalan pada aplikasi. setelah semua tahapan yang telah direncanakan maka proses selanjutnya adalah melakukan pengujian aplikasi. Pengujian yang digunakan adalah mengunakan metode blackbox.

Tabel 3.3 : Pengujian Sistem

\begin{tabular}{lc}
\hline \multicolumn{1}{c}{ Fungsi } & Hasil Pengujian \\
\hline Login & Berhasil \\
\hline $\begin{array}{l}\text { Tambah Data Aset } \\
\text { Laboratorium }\end{array}$ & Berhasil \\
\hline Edit Data Aset Laboratorium & Berhasil \\
\hline $\begin{array}{l}\text { Hapus Data Aset } \\
\text { Laboratorium }\end{array}$ & Berhasil \\
\hline Print Data Aset Laboratorium & Berhasil \\
\hline Cari Data Aset Laboratorium & Berhasil \\
\hline $\begin{array}{l}\text { Tambah Data Aset } \\
\text { Perpustakaan }\end{array}$ & Berhasil \\
\hline
\end{tabular}

\begin{tabular}{ll}
\hline Edit Data Aset Perpustakaan & Berhasil \\
\hline $\begin{array}{l}\text { Hapus Data Aset } \\
\text { Perpustakaan }\end{array}$ & Berhasil \\
\hline Print Data Aset Perpustakaan & Berhasil \\
\hline Cari Data Aset Perpustakaan & Berhasil \\
\hline Tambah Data Aset Ruangan & Berhasil \\
\hline Edit Data Aset Ruangan & Berhasil \\
\hline Hapus Data Aset Ruangan & Berhasil \\
\hline Print Data Aset Ruangan & Berhasil \\
\hline Cari Data Aset Ruangan & Berhasil \\
\hline Tambah Data Aset ATK & Berhasil \\
\hline Edit Data Aset ATK & Berhasil \\
\hline Hapus Data Aset ATK & Berhasil \\
\hline Print Data Aset ATK & Berhasil \\
\hline
\end{tabular}

\section{KESIMPULAN}

Berdasarkan hasil penelitian serta pengujian yang telah dilakukan maka dapat disimpulkan dengan mengunakan metode extreme programming, maka pembuatan aplikasi dapat lebih cepat selesai karena setiap tahapan telah memiliki tahapan perencanaan sampai dengan dengan pengujian dalam menghasilkan aplikasi tersebut, dan hasil dari aplikasi juga diperoleh kesimpulan bahwa dalam aplikasi ini admin dapat dipermudah dalam pencarian informasi asset karena admin dapat mengetahui keadaan asset setiap saat dengan cepat dan tepat.

\section{DAFTAR PUSTAKA}

[1] Erick Kurniawan. (2011). Cepat Mahir Visual Basic basic 2010. Yogyakarta : Andi Publisher.

[2] Suryantara, I Gusti N. S.Kom.,M.Kom (2017). Merancang Aplikasi dengan Metode Extreme Programming. Jakarta : Elex Media Komputindo.

[3] Zugiri, Haris Saputro. (2016). Pengelolaan Database MySQL dengan PHP MyAdmin. Jakarta: Graha Ilmu. 